\title{
ANALISIS PENGGUNAAN DANA DESA TERHADAP EFEKTIVITAS PEMBANGUNAN DESA DALAM MENERAPKAN PERMENDES NO. 19 TAHUN 2017
}

\author{
Oleh: Kencana Dewi ${ }^{1}$, Dwirini ${ }^{2}$, M. Ichsan Siregar ${ }^{3}$ \\ kencanadewi@unsri.ac.id ${ }^{1}$, dwirini@unsri.ac.id ${ }^{2}$, michsansiregar@yahoo.com ${ }^{3}$ \\ (Program Studi Akuntansi, Fakultas Eknomi, Universitas Sriwijaya)
}

\begin{abstract}
Abstrak-Dana desa adalah program kebijakan yang dibuat oleh pemerintah pusat dengan tujuan untuk meningkatkan kesejahteraan masyarakat desa. Peraturan Menteri Desa No.19/2017 pada pasal 1 ayat 23 megatakan bahwa Lumbung Ekonomi Desa adalah upaya mengoptimalkan sumberdaya secara mandiri dalam rangka mewujudkaan kesejahteraan desa. Tujuan penelitian ini adalah untuk menganalisis penggunaan alokasi dana desa terhadap efektivitas pembangunan desa selama tahun 2015-2018 di Desa Desa Manggar Raya Kecamatan Tanjung Lago Kabupaten Banyuasin. Penelitian ini menggunakan pendekatan kuantitatif dan dijabarkan secara deskriptif dengan metode wawancara, dokumentasi dan observasi. Rasio efektivitas dihitung dengan membagi realization dengan budget dikali dengan 100\%. Hasil penelitian menunjukkan penggunaan Alokasi Dana Desa di Manggar Raya yang diberikan tidak maksimal dilihat dari rasio efektivitas dari tahun 2015-2018 yaitu 47,18\%, 64,57\%, 84,99\% dan 84,99\%.
\end{abstract}

Kata Kunci: Pengunaan alokasi dana desa, efektivitas desa, dan Permendes No.19/2017

\begin{abstract}
Village funds are policy programs made by the central government with the aim of improving the welfare of rural communities. Village Minister Regulation No.19/2017 in pasal 1 paragraph 23 states that the Village Economic Barn is an effort to optimize resources independently in order to realize village welfare. The purpose of this study was to analyze the use of village fund allocations on the effectiveness of village development during 2015-2018 in Manggar Raya Village, Tanjung Lago District, Banyuasin Regency. This study uses a quantitative approach and described descriptively with the methods of interview, documentation and observation. The effectiveness ratio is calculated by dividing realization by budget multiplied by $100 \%$. The results showed that the use of Village Fund Allocation in Manggar Raya was not optimal in terms of the effectiveness ratio from 2015-2018, namely 47.18\%, 64.57\%, $84.99 \%$ and $84.99 \%$.
\end{abstract}

Keywords: Use of village fund allocations, village effectiveness, and Permendes No.19/2017

\section{PENDAHULUAN}

Permendagri Nomor 20 Tahun

2018 merupakan Peraturan Menteri
Dalam Negeri tentang Perubahan Pengelolaan Keuangan Desa yang sebelumnya diatur melalui Peraturan 
Menteri Dalam Negeri Nomor 113 Tahun 2014. Keuangan Desa menurut Permendagri 113/2014 adalah semua hak dan kewajiban desa yang dapat dinilai dengan uang serta segala sesuatu berupa uang dan barang yang berhubungan dengan pelaksanaan hak dan kewajiban desa.

Permendes No. 19 Tahun 2017 tentang Prioritas Penggunaan Dana Desa, kesesuaian rencana dan program kerja serta menganalisis kendala-kendala yang dihadapi pemerintah desa. Desa sebagai pemerintahan di tingkat paling bawah yang langsung bersentuhan dengan masyarakat yang menjadi hal utama dalam keberhasilan pembangunan pemerintah, ini dikarenakan sebagian besar wilayah Indonesia ada di perdesaan. Pemerintah Daerah diberikan otonomi yang lebih luas dalam membiayai dan mengelola pembangunan daerahnya berdasarkan prioritas anggaran mereka sendiri. Maka diharapkan kepada kepala desa memiliki ruang luas untuk merumuskan dan melaksanakan kebijakan pembangunan berdasarkan kebutuhan didaerah mereka sendiri melalui Alokasi Dana Desa (ADD).

Penggunaan keuangan baik dari segi anggaran maupun sampai realisasi harus melibatkan tokohtokoh masyarakat dan aparat Pemerintah Desa. Fenomena, berdasarkan hasil pemantauan Indonesia Corruption Watch (ICW) pada Kompas Tanggal 21 November 2018, menyatakan bahwa sejak tahun 2015 sampai dengan awal tahun 2018, terdapat 181 kasus korupsi dana desa dengan 184 kepala desa sebagai tersangka korupsi dan nilai kerugian sebesar $\operatorname{Rp}$ 40,6 miliar.

Intinya ADD memiliki pengaruh yang besar dan juga signifikan terhadap pembangunan sebuah desa di setiap kabupaten yang ada di Indonesia. Oleh karena itu, peneliti lebih memilih penggunaan ADD Manggar Raya salah satu desa yang berada di Kecamatan Tanjung Lago Kabupaten Banyuasin. Sumber pendapatan dana desa itu dapat diperoleh dari Pendapatan Asli Daerah (PAD), dana desa yang bersumber dari APBN, bagian dari hasil PDRB Kabupaten/Kota, Alokasi Dana Desa Kabupaten/Kota, bantuan keuangan dari APBD provinsi dan APBD Kabupaten/Kota, Hibah dan Sumbangan pihak ketiga, serta lain-lain pendapatan desa yang sah.

Selanjutnya, sesuai dengan APBN Tahun Anggaran 2018 pemerintah mengalokasikan dana desa TA 2018 yang ditujukan untuk meningkatkan perekonomian desa, mengatasi kesenjangan pembangunan antar desa, serta memperkuat masyarakat desa sebagai subjek dalam pembangunan. Penggunaan ADD rawan terhadap penyelewengan dana oleh pihak yang seharusnya dapat dipercaya oleh 
masyarakat dalam membangun desa menjadi lebih maju dan berkembang.

Oleh sebab itu, peran masyarakat sangat penting sebagai pengawas langsung dan tidak lepas dari peran dari peran pemerintah kabupaten selaku pemberi dana untuk memonitor jalannya pembangunan di desa. Adapun aliran penggunaan dana desa sebesar $70 \%$ diperuntukkan bagi pemberdayaan masyarakat dan sisanya $30 \%$ diperuntukkan bagi penyelenggaraan pemerintah desa.

Masyarakat desa sebagai subjek dalam pembangunan dapat dikatakan masyarakat sudah semestinya mendapat perhatian yang lebih guna menunjang sebuah pembangunan yang optimal. Apabila masyarakat desa aktif diberdayakan dalam pembangunan, maka akan menunjang kualitas sumber daya manusia (human resources) serta akan meningkatkan kesejahteraan hidup masyarakat pedesaan dan akan berdampak pada peluang kesempatan kerja dan lapangan kerja. Desa Manggar Raya merupakan salah satu desa di Sumatera Selatan yang mendapat kucuran anggaran Dana Desa sebesar Rp 786.872.991 lebih dari Anggaran Pendapatan Belanja Negara (APBN) tahun 2018. Desa Manggar Raya adalah sebuah desa yang terletak di Sumatera Selatan, Indonesia.Jarak yang ditempuh dari ibukota Palembang ke desa Manggar Raya adalah $\pm 65 \mathrm{~km}$ dan mempunyai wilayah seluas $3.958 \mathrm{~km}^{2}$ dengan jumlah penduduk adalah 2.567 jiwa.Besarnya dana desa yang diterima oleh Pemerintah Desa Manggar Raya saat tahun $2015 \mathrm{Rp}$. 295.670.000 dibandingkan dengan alokasi dana desa yang diterima saat tahun 2016 sebesar Rp. 632.500.785 mengalami peningkatan yang signifikan.

Penggunaan Alokasi Dana Desa dapat berjalan dengan baik akan menghasilkan pembangunan desa yang optimal, baik dari segi pembangunan fisik maupun pembangunan non fisik. Pembangunan fisik berupa pembangunan fasilitas bagi masyarakat desa seperti jalan, rumah ibadah, posyandu dan sebagainya. Sedangkan untuk pembangunan non fisik dapat berupa pembekalan sumber daya manusia untuk masyarakat desa seperti karang taruna ataupun penyuluhan terhadap berbagai masalah yang penting seperti penyuluhan keluarga berencana, penyuluhan penguatan ketahanan pangan ataupun pengentasan buta huruf.

Berbagai persoalan dan permasalahan yang menarik untuk dikaji lebih mendalam berkaitan dalam proses penggunaan ADD, yaitu bagaimana penggunaan Alokasi Dana Desa (ADD) terhadap efektivitas pembangunan desa dalam Menerapkan Permendes No. 19 Tahun 2017 pada Tahun Anggaran 2015-2019 di Desa Manggar Raya 
Kecamatan Tanjung Lago Kabupaten Banyuasin?.

Definisi akuntabilitas menurut Mardiasmo (2006), menerangkan bahwa pengertian akuntabilitas adalah: "Akuntabilitas adalah kewajiban pihak pemegang amanah (agent) untuk memberikan pertanggung jawaban, menyajikan, melaporkan, dan mengungkapkan segala aktifitas dan kegiatan yang menjadi tanggung jawabnya kepada pihak pemberi amanah (prinscipal) yang memiliki hak dan kewenangan untuk meminta pertanggung jawaban tersebut."

Akuntabilitas dalam konteks pemerintahan mempunyai arti pertanggungjawaban yang merupakan salah satu ciri dari terapan good governance. Pemikiran ini bersumber dari pemikiran administrasi publik merupakan isu menuju clean government.

Akuntabilitas dilihat dari sudut pandang pengendalian merupakan tindakan pada pencapaian tujuan. Dalam pengelolaan keuangan daerah dituntut adanya pertanggungjawaban kepada publik yang dapat dilakukan secara institusional kepada DPRD. DPRD akan menilai apakah kinerja pemda yang bersangkutan dalam mengelola keuangan daerah atau APBD baik atau buruk dengan menggunakan kriteria atau tolok ukur sesuai apa yang direncanakan semula.

Zulham Afandi

melakukan yang berjudul penelitian manjemen Alokasi Dana Desa (ADD) Tahun 2013 Di Desa Mekar Sari Kecamatan Merbau Kabupaten Meranti menggunakan analisis deskriptif. Hasil penelitian ini menyimpulkan bahwa pengelolaan anggaran dana desa pemerintah/tim pelaksana ADD belum maksimal.

Tatik Rohmah

(2016)

melakukan yang berjudul penelitian pemanfaatan Alokasi Dana Desa dalam Meningkatkan Pembangunan Infrastruktur di Desa Bektiharjo Kecamatan Semandi Kabupaten Tuban. Hasil penelitian dengan analisis deskriptif menyatakan bahwa pemanfaatan ADD dalam meningkatkan pembangunan infrastruktur desa sudah berjalan dengan baik.

Di tahun 2017, Novianti Ruru melakukan penelitian dengan judul analisis penerapan alokasi Dana Desa (ADD) dalam upaya meningkatkan pembangunan Desa : Studi Kasus Desa Suwan Kecamatan Kalawat Kabupaten Minahasa Utara. Hasil penelitian dengan analisis deskriptif menyatakan bahwa penerapan alokasi dana desa pada Desa Suwaan sudah berjalan sesuai dengan Peraturan Bupati No. 22 Tahun 2016 Tentang Pemberian Alokasi Dana Desa Kepada Pemerintah Desa se-Kabupaten Minahasa Utara.

Efektivitas dapat dinilai dengan berbagai cara dan memiliki kaitan yang erat dengan efesiensi. Alat efektivitas yang digunakan 
untuk menggambarkan kemampuan Pemerintah Desa dalam merealisasi pengalokasian dana desa untuk melaksanakan program pembangunan yang direncanakan dibandingkan dengan target yang telah ditetapkan berdasarkan potensi nilai rill. Formula tingkat efektivitas pembangunan desa pada Desa Manggar Raya dari tahun 2015-2018 menggunakan rumus sebagai berikut Depdagri, Kemendagri no 690.900.327.

$$
\text { Effectiveness }=\frac{\text { realization } A D D}{\text { budget } A D D}
$$

\section{Menurut Beni Pekei} (2016:172) Efektivitas adalah ukuran berhasil tidaknya pencapaian tujuan suatu organisasi. Apabila suatu organisasi mencapai tujuan maka organisasi tersebut telah berjalan dengan efektif.

Hasil simpulan perbandingan realization dan budget dana desa dapat di lihat dari rasio efektivitas, dengan penjelasan sebagai berikut:

1) Hasil pencapaian diatas $100 \%$ diartikan sangat efektif.

2) Hasil pencapaian 90-100\% diartikan efektif.

3) Hasil pencapaian $80-89 \%$ diartikan cukup efektif.

4) Hasil pencapaian $60-79 \%$ diartikan kurang efektif.

5) Hasil pencapaian < 60\% diartikan tidak efektif.

Terdapat indikator-indikator yang akan digunakan dalam penelitian ini maka kerangka pemikiran yang dikembangkan dapat digambarkan sebagai berikut:

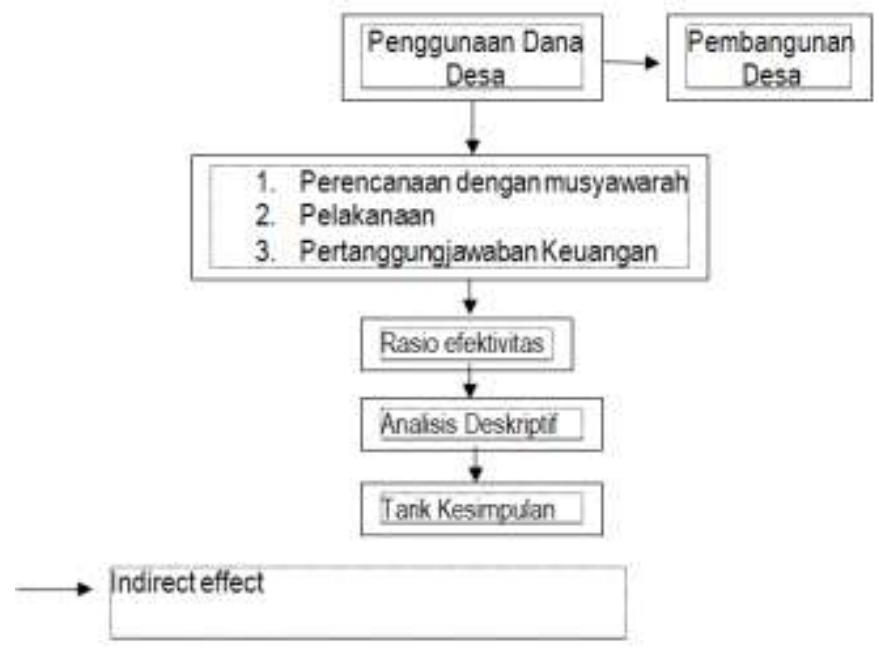

Gambar 1. Research Model (Sumber: Diolah, 2021)

Penggunaan Dana Desa Lago Kabupaten Banyuasin Manggar Raya Kecamatan Tanjung didasarkan pada Peraturan Bupati 
No.5 Tahun 2016 tentang Petunjuk Teknis Pengelolaan Keuangan dan Kegiatan Desa Dalam Kabupaten Banyuasin dan Peraturan Daerah No.1 Tahun 2016 tentang PokokPokok Pengelolaan Keuangan Daerah. Seluruh hak dan kewajiban yang dapat dinilai dengan uang serta segala sesuatu baik berupa uang/barang dapat dijadikan milik desa sehingga perlu di kelola dalam suatu sistem pengelolaan keuangan desa dan perimbangan keuangan kabupaten dan desa.

Ilustrasi, dalam proses penggunaan ADD yang di Desa Manggar Raya belum sesuai dengan prinsip-prinsip akuntansi yang berterima umum (PABU) sehingga berdampak belum efektifnya pencapaian tujuan ADD seperti pembangunan. Hal tersebut dapat dilihat dari segi perencanaan, pelaksanaan, dan pertanggungjawaban keuangan desa.

\section{METODE PENELITIAN}

Unit analisis dalam penelitian ini adalah seluruh masyarakat desa Manggar Raya. Penarikan sampel penelitian ini menggunakan teknik purposive sampling. Teknik purposive sampling adalah teknik pengambilan sampel dengan cara sengaja yang telah sesuai dan memenuhi segala persyaratan yang dibutuhkan yaitu sifat, ciri dan kriteria sampel tertentu. Teknik purposive sampling pertama adalah perangkat desa yang berjumlah 4 orang dengan jabatan sebagai Kepala Desa, Bendahara, Sekretaris Desa dan Ketua LPM.

Teknik purposive sampling kedua adalah tokoh masyarakat yang berjumlah 5 orang yang masingmasing sebagai tokoh agama, tokoh adat, tokoh pemuda dan kepala dusun. Teknik purposive sampling ketiga adalah masyarakat yang berjumlah 41 orang. Secara keseluruhan responden pada teknik purposive sampling adalah 50 orang.

Pengumpulan data primer dilakukan dengan wawancara perangkat desa, dan tokoh masyarakat yang menanyakan tiga hal yaitu (1) Perencanaan Desa melalui Musrenbangdesa tentang usulan-usulan kegiatan rencana pembangunan; (2) Pelaksanaan kegiatan pembangunan secara transparansi;(3) Pertanggungjawaban keuangan dengan disiplin menyusun laporan pertanggungjawaban pada akhir tahun dan evaluasi dengan masyarakat atas kegiatan pembangunan yang telah terjadi di tahun berjalan.

Data-data tersebut diolah dengan menggunakan metode deskriptif dan rasio effectiveness untuk membandingkan keluaran dengan hasil yang telah tercapai. dan rasio effectiveness diukur dengan membandingkan realization dana desa dan budget dana desa dengan menggunakan analisis deskriptif. Apabila nilai "realization" lebih besar dari nilai "budget" maka 
dikategorikan sangat efektif, sebaliknya bila nilai "realization" lebih kecil atau sama dengan nilai "budget" maka kurang/tidak efektif.

\section{HASIL DAN PEMBAHASAN}

Penelitian ini dilakukan di Desa Manggar Raya Kecamatan Tanjung Lago Kabupaten Banyuasin. Manggar Raya adalah sebuah desa kecil terletak di Provinsi Sumatera Selatan dengan luas wilayahnya kurang lebih $3.958 \quad \mathrm{~km} 2$. Kebanyakkan bermata pencaharian sebagai petani karet, sawit dan tanaman palawija padi. Mata pencaharian lain sebagai pedagang. Dengan jumlah penduduk 2.567 jiwa.

Penelitian ini diikuti oleh 50 responden yang diwakili oleh Perangkat Desa, Tokoh Masyarakat, dan Masyarakat setempat.

Hasil wawancara yang dilakukan dengan para perangkat desa dan masyarakat setempat menunjukkan bahwa langkah awal yaitu perencanaan alokasi Dana Desa di Desa Manggar Raya, telah sesuai dengan ketentuan yang berlaku. Terlihat dari adanya tim pelaksana dan proses perencanaan dilakukan dengan model partisipatif dalam kegiatan musrenbang.

Akan tetapi, dari hasil pengamatan dan informasi yang diperoleh menunjukkan bahwa kegiatan musrenbang dalam tahapan perencanaan di Desa Manggar Raya masih sebatas memenuhi ketentuan dan belum menyentuh kepada esensi yang terkandung dari maksud kegiatan MusrenbangDesa. Pada akhinya penyusunan rencana kegiatan Alokasi Dana Desa yang tertuang dalam DURK dapat terselesaikan dengan baik. Namun karena rencana yang dihasilkan tidak berdasarkan aspirasi masyarakat serta kurangnya transparansi informasi dan pemerintah desa, maka dapat dikatakan bahwa tahap perencanaan alokasi dana desa dalam upaya meningkatkan efektivitas program pembangunan di Desa Manggar Raya Kecamatan Tanjung Lago Kabupaten Banyuasin masih kurang baik.

$\begin{array}{ccr}\text { Hasil } & \text { penelitian } & \text { ini } \\ \text { menunjukan } & \text { bahwa } & \text { dalam } \\ \text { pelaksanaan } & \text { rencana } & \text { kegiatan }\end{array}$ pemerintah desa masih kurang transparan dalam memberikan informasi kepada masyarakat. Kurangnya transparansi informasi yang dimaksud adalah bahwa dalam pelaksanaan rencana kegiatan, pemerintah desa tidak terlebih dahulu memberikan informasi atau meminta partisipasi masyarakat, kondisi inilah yang menjadi salah satu penyebab rendahnya tingkat partisipasi masyarakat dalam mendukung kegiatan pembangunan desa. Akan tetapi walaupun semua rencana yang telah disusun dapat terselesaikan dengan cukup baik, namun tahap pelaksanaan alokasi dana desa dalam upaya meningkatkan efektivitas 
pembangunan di Desa Manggar Raya dapat dikatakan masih belum efektif.

$$
\text { Penyelesaian penyusunan }
$$
pertanggungjawaban Dana Desa dalam upaya meningkatkan efektivitas program pembangunan di Desa Manggar Raya, dalam tahap pertanggungjawaban ini dikatakan belum efektif, dimana penyusunan Laporan Pertanggungjawaban (LPJ) belum disusun oleh pemerintah desa, namun penyusunan laporan pertanggungjawaban ini disusun dan diselesaikan oleh pihak ketiga yang bukan berasal dari pihak pemerintah serta tidak ada transparansi kepada masyarakat, sehingga masyarakat tidak mengetahui tanggungjawab mereka sebagai tim evaluasi dari setiap kegiatan yang dilakukan dalam penggunaan DD. Walaupun secara administrasi tahapan pertanggungjawaban oleh pemerintah Desa Manggar Raya dapat diselesaikan dan tidak adanya evaluasi kegiatan yang seharusnya dilakukan bersama masyarakat Desa Manggar Raya. Maka tahapan pertanggungjawaban yang dilakukan oleh pemerintah Desa Manggar Raya dapat dikatakan kurang efektif.

Ratio effectiveness yang lebih tinggi dapat disebabkan oleh beberapa alasan. Ini termasuk strategi penanggulangan kemiskinan, peningkatan kegiatan perencanaan dan penganggaran pembangunan desa, peningkatan infrastruktur desa, dan peningkatan kegiatan desa lainnya.

Hasil analisis data disajikan pada Tabel 1 di bawah ini.

Tabel 1. Analisis Data

\begin{tabular}{|c|c|c|c|c|}
\hline \multirow{2}{*}{ Tahun } & \multicolumn{2}{|c|}{ Pembangunan Desa } & \multirow{2}{*}{$\begin{array}{c}\text { Rasio } \\
\text { Efektivitas }\end{array}$} & Kriteria \\
\cline { 2 - 3 } & Realisasi & Anggaran & Tidak Efektif \\
\hline 2015 & 139.500 .000 & 295.670 .000 & $47,18 \%$ & Kurang Efektif \\
\hline 2016 & 408.432 .814 & 632.500 .785 & $64,57 \%$ & Cukup Efektif \\
\hline 2017 & 672.186 .345 & 790.872 .991 & $84,99 \%$ & Cukup Efektif \\
\hline 2018 & 668.850 .000 & 786.887 .132 & $84,99 \%$ & \multicolumn{2}{|c}{} \\
\hline
\end{tabular}

Sumber: BKU Kantor Desa Manggar Raya (diolah)

Pada tahun 2015 pembangunan desa yang di anggarkan untuk alokasi dana desa sebesar Rp. 295.670.000,dengan tingkat Ratio effectiveness $47,18 \%$ dengan katagori tidak efektif. Sedangkan daya serap anggaran yang dikeluarkan pada tahun 2015 sebesar Rp. 139.500.000,-. Selisih alokasi dana desa yang tidak terserap sebesar Rp. 156.170.000,-. Pada tahun 2016 pembangunan desa yang di 
anggarkan untuk alokasi dana desa sebesar Rp. 632.500.785,- dengan tingkat rasio efektivitas $64,57 \%$ dengan katagori kurang efektif. Sedangkan daya serap anggaran yang dikeluarkan pada tahun 2016 sebesar Rp. 408.432.814,-. Selisih alokasi dana desa yang tidak terserap sebesar Rp. 224.067.971,-. Pada tahun 2017 pembangunan desa yang di anggarkan untuk alokasi dana desa sebesar Rp.790.872.991,- dengan tingkat rasio efektivitas $84,99 \%$ dengan katagori cukup efektif. Sedangkan daya serap anggaran yang dikeluarkan pada tahun 2017 sebesar Rp. 672.186.345,-. Selisih alokasi dana desa yang tidak terserap sebesar Rp. 118.686.646,-. Pada tahun 2018 pembangunan desa yang di anggarkan untuk alokasi dana desa sebesar Rp.786.887.132,- dengan tingkat rasio efektivitas $84,99 \%$ dengan katagori cukup efektif. Sedangkan daya serap anggaran yang dikeluarkan pada tahun 2018 sebesar Rp. 668.850.000,-. Selisih alokasi dana desa yang tidak terserap sebesar Rp. 118.037.132,-.

Maka dapat disimpulkan bahwa pemberian Alokasi Dana Desa merupakan wujud dari pemenuhan hak desa untuk menyelenggarakan Otonomi Desa agar tumbuh dan berkembang mengikuti pertumbuhan dari desa itu sendiri berdasarkan keanekaragaman, partisipatif, otonomi asli, demokratisasi dan pemberdayaan masyarakat tetapi daya serap dari alokasi dana desa yang diberikan tidak maksimal dilihat dari ratio effectiveness dari tahun 2015-2018 $(47,18 \%, 64,57 \%, 84,99 \%, 84,99 \%)$.

\section{KESIMPULAN}

Berdasarkan hasil observasi dan kajiannya maka dapat ditarik beberapa kesimpulan bahwa: (1) penggunaan alokasi Dana Desa terhadap efektivitas pembangunan di Desa Manggar Raya Kecamatan Tanjung Lago Kabupaten Banyuasin terdapat tiga tahap antara lain, tahap perencanaan, pelaksanaan dan pertanggungjawaban. Berdasarkan hasil penelitian dari tiga tahap penggunaan Alokasi Dana Desa secara administratif sudah sesuai dengan Permendes No. 19 Tahun 2017 tentang Penetapan Prioritas Penggunaan Dana Desa. Akan tetapi, keikutsertaan masyarakat dalam pengelolaan Alokasi Dana Desa masih kurang karena minimnya pengetahuan yang dipahami mengenai penggunaan Alokasi Dana Desa yang akibatnya masyarakat menjadi tidak merespon kegiatan pengelolaan Alokasi Dana Desa. (2) Efektivitas pembangunan desa dihitung dengan membagi realisasi dengan anggaran dikali dengan 100 $\%$. Selama tahun 2015 sampai dengan 2018 besarnya ratio effectiveness pembangunan desa masih tidak stabil, dan belum mencapai kategori yang efektif.

Keakuratan peneliti selanjutnya diharapkan mampu menganalisis 
lebih detail lagi dan mengambil sampel kabupaten yang berbeda diluar Desa Manggar Raya. Hal ini dimaksudkan agar dapat membandingkan bagaimana kesiapan dan hasil dari kinerja pemerintah desa di kabupaten yang lainnya.

\section{UCAPAN TERIMAKASIH}

Penelitian ini dapat dilaksanakan dengan baik dan lancar berkat bantuan dari berbagai pihak, untuk itu peneliti mengucapkan terima kasih kepada Kepala Desa, Sekretaris Desa, Toko Masyarakat dan Tokoh Agama di Desa Manggar Raya, Ketua Jurusan Akuntansi, dan semua pihak yang telah banyak memberikan bantuan dalam penyelesaian penelitian ini.

\section{DAFTAR PUSTAKA}

Abdul Rohman dan Ika Sasti, Ermadiani. 2018. "Pengelolaan Administrasi Keuangan Pemerintah Desa".Yogyakarta: Sekolah Tinggi Ilmu Manajemen YKPN.

Devas, Nick. 1989. "Keuangan Pemerintah Daerah di Indonesia" (terjemahan Masri Maris). Jakarta: Universitas Indonesia.

Mardiasmo. 2006. Perwujudan Transparansi dan Akuntabilitas Publik Melalui Akuntansi Sektor Publik : Suatu Sarana Good Governance. Jurnal Akuntansi Pemerintahan, Vol.2 : No.1 (Hal1-17)
Novianti Ruru, Kalangi Lintje, Novi S. Budiarso. 2017. "Analisis Penerapan Alokasi Dana Desa (ADD) Dalam Upaya Meningkatkan Pembangunan Desa (Studi kasus Desa Suwaan, Kec.Kalawat, Kab. Minahasa Utara)". eJurnal Universitas Sam Ratulangi, 12(1): 83-90.

Nurcholis, Amin. 2013 "Pertumbuhan dan Penyelenggaraan Pemerintahan Desa". Jakarta: Erlangga.

Pekei, Beni. 2016. "Konsep dan Analisis Efektivitas

Pengelolaan Keuangan Daerah Otonomi". Jakarta: TAUSHIA. Peraturan Bupati Kabupaten Banyuasin No.5 Tahun 2016 tentang Petunjuk Teknis Pengelolaan Keuangan dan Kegiatan Desa Dalam Kabupaten Banyuasin.

Peraturan Menteri Dalam Negeri Nomor 59 Tahun 2007 Tentang Efektivitas.

Peraturan Menteri Dalam Negeri Nomor 20 Tahun 2018 Keuangan Desa.

Peraturan Menteri Dalam Negeri Nomor 114 Tahun 2014 Pembangunan Desa.

Peraturan Menteri Desa Nomor 19 Tahun 2017 tentang Prioritas Penggunaan Dana Desa.

Rosalinda Okta, 2014. "Pengelolaan Alokasi Dana Desa (ADD) Dalam Menunjang Pembangunan Pedesaan”. 
eJurnal Universitas Brawijaya, 2014, 2(2): 17-33.

Salim, P. 1991. Kamus Bahasa

Kontemporer. Jakarta : Modern English Fresh. Silalahi, Ulber. 2012. Metode Penelitian Sosial. Bandung: Reflika Aditama.

Sutrisno. 2013. "Manajemen Keuangan Teori, Konsep dan Aplikasi”. Yogyakarta: Ekonisia.

Stewart, J.D. 1984. "The Role Of Information In Public Accountability". Anthony Hopwood and Cyril, R. Tomkins, Eds, "Issue In Public Sector Accounting”, Oxford. England Philip Alan.

Tatik Rohmah. 2016. "Pemanfaatan

Alokasi Dana Desa Dalam Meningkatkan Pembangunan Infrastruktur di Desa Bektiharjo kecamatan Semanding Kabupaten Tuban". eJurnal Universitas Negeri Surabaya,1(1): 1-11.

Toha, Suherman. 2007. Penelitian Masalah Hukum Tentang Penerapan Good Coorporate Governance Pada Dunia Usaha. Badan Pembina Hukum Nasional Departemen Hukum dan Hak Asasi Manusia.

Thomas. 2013. "Pengelolaan Alokasi Dana Desa Dalam Upaya Meningkatkan Pembangunan Di Desa Sebawang Kecamatan Sesayap Kabupaten Tana
Tidung". eJurnal Universitas Mulawarman, 1(1): 51-64.

Tumbel. 2014. "Analisis Bantuan Desa Terhadap Pelaksanaan Pembangunan Desa (Studi kasus Kec. Tareran, Kab. Minahasa Selatan)". eJurnal Universitas Sam Ratulangi, 1(2): 1-12. Undang-Undang Nomor 6 Tahun 2014 Tentang Desa. Undang-Undang Nomor 32 Tahun 2004 tentang Pemerintahan Daerah

Widodo. $2017 . \quad$ "Analisis Pengelolaan Alokasi Dana Desa Dalam Pemberdayaan Masyarakat Desa Karangluhur". eJurnal Universitas Diponogoro, 1(2): 25-48.

Widodo, Joko. 2011. "Analisis kebijakan publik (Konsep dan Aplikasi ProsesKebijakan Publik)". Malang: Bayumedia. 